\section{Severe restless legs syndrome presenting as intractable insomnia}

I. Arnulf, MD, PhD, E. Konofal, MD, PhD, C. Gauthier, MD, F. Chedru, MD, Paris, France

A 62-year-old man consulted the sleep clinic. He had a 20-year history of severe insomnia that was considered of psychiatric origin, although the symptoms were not alleviated by benzodiazepines (clonazepam, flunitrazepam, loflazepam), antidepressants (amitriptyline, mianserin), phenothiazine (alimemazin), amantadine, biperiden, or magnesium salts. He had frequent and longlasting nocturnal arousals, and slept less than 4 hours a night. $\mathrm{He}$ had a strong feeling of discomfort (but no pain) in his legs during the night, which he was able to alleviate temporarily by walking in his garden and massaging his legs (video 1). He scored 31 (very severe) on the scale of the International Restless Legs Syndrome Study Group. ${ }^{1}$ He reported that he was agitated during the night, both when awake and asleep, and had frequently fallen out of bed He was exhausted and had excessive daytime sleepiness (Epworth sleepiness score 13 , normal $<11$ ). He considered these problems to be responsible for his two divorces. There was no family history of restless legs syndrome. Results of general physical and neurologic

Address correspondence and reprint requests to Dr. Isabelle Arnulf, Fédération des Pathologies du Sommeil, Hôpital Pitié-Salpêtrière, 47-83 Boulevard de l'Hôpital, 75651 Paris Cedex 13,France; e-mail: isabelle.arnulf@ psl.ap-hop-paris.fr
Neuro Images

examinations were normal. Serum ferritin level was low $(29 \mu \mathrm{g} / \mathrm{L})$. During nighttime sleep recordings, he fell asleep within 4 minutes. Total sleep time was 297 minutes. He had a mild sleep hypopnea syndrome (18 hypopnea per hour, no apnea). Sleep fragmentation was high $(123$ arousals per hour, normal $<10)$ due to severe periodic leg movements (164 per hour) with dramatic jerks of one or both legs, and sometimes the arms (video 2).

Because the patient met the criteria for restless legs syndrome associated with periodic leg movements during sleep, we prescribed an evening dose of ropinirole, incremented progressively from 0.5 to $3 \mathrm{mg}$, associated with domperidone $(10 \mathrm{mg})$ and a morning dose of iron sulfate $(80 \mathrm{mg})$. The restlessness disappeared, total sleep duration increased from the first night on ropinirole, with no side effects (nausea or orthostatic hypotension). The patient is now stabilized with ropinirole $3 \mathrm{mg}$ in the evening. He sleeps 7 hours a night and is no longer drowsy during the day.

The 20-year delay in the diagnosis and treatment was avoidable. Severe restless legs syndrome and periodic leg movements during sleep are often underdiagnosed, although they may affect up to $1 \%$ of adults ${ }^{2}$ and can be treated effectively with low dose dopamine agonists.

1. The International Restless legs Syndrome Study Group. Validation of the International Restless legs Syndrome Study Group rating scale for restless legs syndrome. Sleep Med 2003;4:121-132.

2. Ohayon MM, Roth T. Prevalence of restless legs syndrome and periodic limb movement disorder in the general population. J Psychosom Res 2002;53:547-554. 


\section{Neurology}

\section{Severe restless legs syndrome presenting as intractable insomnia}

I. Arnulf, E. Konofal, C. Gauthier, et al.

Neurology 2004;62;E19

DOI 10.1212/WNL.62.8.E19

\section{This information is current as of April 26, 2004}

\section{Updated Information \&}

Services

Supplementary Material

References

Permissions \& Licensing

Reprints including high resolution figures, can be found at: http://n.neurology.org/content/62/8/E19.full

Supplementary material can be found at: http://n.neurology.org/content/suppl/2004/04/04/62.8.E19.DC1

This article cites 2 articles, 0 of which you can access for free at: http://n.neurology.org/content/62/8/E19.full\#ref-list-1

Information about reproducing this article in parts (figures,tables) or in its entirety can be found online at:

http://www.neurology.org/about/about_the_journal\#permissions

Information about ordering reprints can be found online:

http://n.neurology.org/subscribers/advertise

Neurology ${ }^{\circledR}$ is the official journal of the American Academy of Neurology. Published continuously since 1951, it is now a weekly with 48 issues per year. Copyright . All rights reserved. Print ISSN: 0028-3878. Online ISSN: 1526-632X.

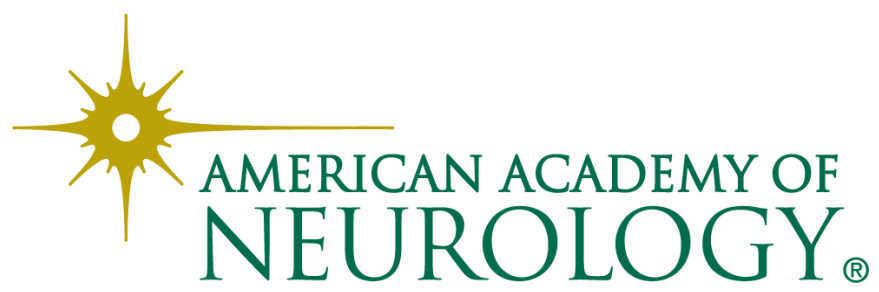

